\title{
Breeding Ecology of Van Dam's Vanga Xenopirostris damii, an Endemic Species in Madagascar
}

\author{
Taku Mizuta*, Masahiko Nakamura** and Satoshi Yamagishi*
}

\begin{abstract}
The family Vangidae is monophyly group of species which underwent extensive in situ radiation within Madagascar. Although the foraging ecology and the phylogeny of this family have been studied, basic information on the breeding biology of each species is poorly known. We described the breeding ecology of Van Dam's Vanga Xenopirostris damii, which is endemic to Madagascar, and considered the mating system of this species. The research was conducted at Ampijoroa Forest Station in the Ankarafantsika Strict Nature Reserve during October to November in 2000. Six pairs were observed in the study area. Each pair had home range which did not overlapped with each other. No interaction was observed among pairs. Parental activities in nest building, incubation and nestling stages were observed at three nests. Both sexes participated in these activities, and no helpers were observed. The non-overlapping home ranges and biparental care suggest that the mating system of Van Dam's Vanga is socially monogamy.
\end{abstract}

Key words: biparental care, madagascar, mating system, monogamy, Van Dam's Vanga.

キーワード：両親による子の世話, マダガスカル, 配偶様式, 一夫一妻, シロ ドオオハシモズ.

\section{Introduction}

The family Vangidae is endemic to Madagascar, and is thought to comprise 14 (Langrand 1990) or 15 (Goodman et al. 1997) species. The ecological radiation of this family is comparable to that of Hawaiian honeycreepers and Gálapagos finches. Yamagishi and Eguchi (1996) investigated the foraging behaviour of 13 species of vangids, and suggested that the species segregated according to bill type, geographic range, and/or foraging niche, to avoid interspecific competition. Using their mitochondrial DNA sequence data for the 12s and 16s rRNA genes, Yamagishi et al. (2001) documented that the family is monophyletic and underwent extensive in situ radiation. Although study of vangid species' breeding ecology in relation to phylogeny and foraging ecology is important to understanding the adaptive radiation of this family, there have been only a few studies, yielding limited data (see Appert 1970, Yamagishi et al. 1995, Putnam 1996, Rakotomanana et al. 2000, Nakamura et al. 2001). Van Dam's Vanga (Xenopirostris damii) is one of the rarest and most threatened of all the vangid species, because of its limited range (Langrand 1990). This species is found in only one part of the western deciduous dry forest, and nothing is known of its breeding biology. The present study

Received 6 April 2001, Revised 25 May 2001, Accepted 13 June 2001

* Laboratory of Ethology, Graduate School of Science, Kyoto University, Kitashirakawa-Oiwake-cho, Sakyo-ku, Kyoto 606-8502, Japan.

** Laboratory of Animal Ecology, Department of Biology, Joetsu University of Education, 1 Yamayashikimachi, Joetsu-shi, Niigata 943-8512, Japan. 
is the first descriptive data for the basic breeding ecology of Van Dam's Vanga. In the study we infer its mating system from data on home range distribution, nesting activity, and foraging ecology.

\section{Materials and Methods}

The study was conducted in Jardin Botanique A, Ampijoroa Forest Station $\left(16^{\circ} 15^{\prime}\right.$ $\mathrm{S}, 46^{\circ} 48^{\prime} \mathrm{E}, 200 \mathrm{~m}$ above sea level), approximately $110 \mathrm{~km}$ southeast of Mahajanga, northwestern Madagascar. Jardin Botanique A is a research quadrat $(450 \mathrm{~m} \times 550 \mathrm{~m})$ with many trails inside it and at its periphery. This forest is part of the Ankarafantsika Strict Nature Reserve, classified as a western deciduous dry forest (Langrand 1990). It is a deciduous broad-leaved forest, dominated by trees of three Strichnos species (see Yamagishi et al. [1995] for a more detailed description of the site).

Our research was conducted from 7 October to 17 November 2000. We walked in the forest to search for nests and individuals in the morning $(05: 00$ to $11: 30)$ and afternoon (15:00 to $17: 30$ ) every day except for 23 October. A bird was followed until we lost sight of it, and we recorded the location of the point of encounter, and bird behaviours. The trajectory of the bird was then plotted on a map. The outermost points of encounter per individual were connected to form a convex polygon that represented the individual's home range. We detected nests by following birds during their nest-building and

Nest B

\section{Female}

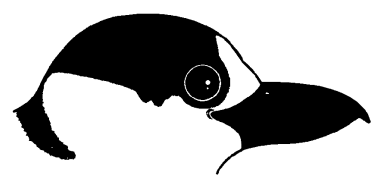

(Right)

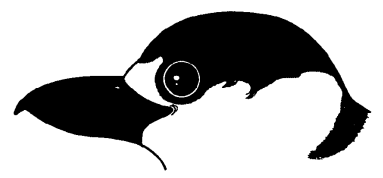

(Left)

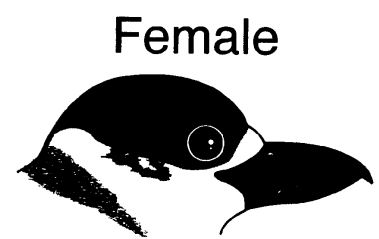

(Right)
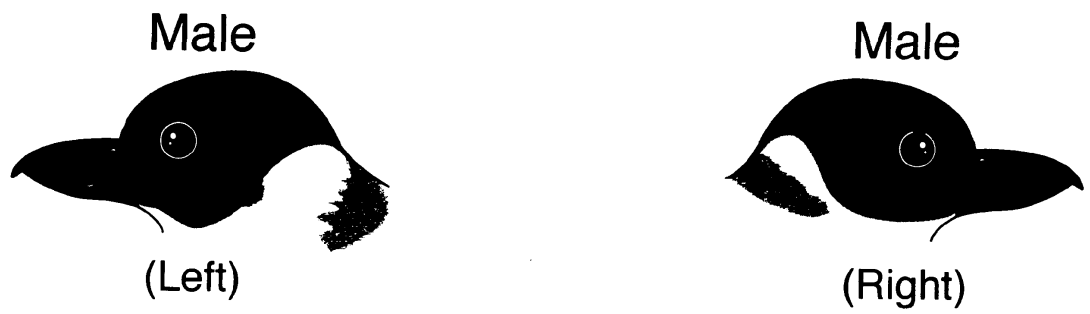

Fig. 1. Examples of individual discrimination based on variation in the shape of the black cap, flaws on the bill, and inflammation around the eye. 
incubation stages. We used parent behaviour to infer the dates of egg-laying, egghatching, or disappearance of eggs or nestlings: when parents were first observed to sit on the nest for a certain duration after the nest building stage, we inferred that they started egg-laying. We regarded the eggs hatched when the parents were first observed to bring the food item to the nest. When parents stopped to come to the nest during the incubation or nestling stages, we regarded that the eggs or nestlings disappeared.

Head colour was used to sex individuals: the black cap of females is less extensive than that of males, and foreheads are whitish for females and black for males (Langrand 1990, Morris \& Hawkins 1998, see Fig. 1). We were able to discriminate individuals of each sex by using variation in the shape of the black cap, flaws on the bill, and inflammation around the eye (Fig. 1). In addition, the extent of tinged buff colour on the breast and belly varied among female individuals.

The height above ground and the DBH (diameter at breast height) of nesting trees were measured for each nest. Three nests were found and observed for more than 41 hours, using a $20-40 \times$ spotting scope and a Hi8 video camera (SONY Handycam CCD-TRV92) from approximately $20 \mathrm{~m}$ away. Each observation period was 3-4 hours long, between $07: 30$ and $11: 30$. We recorded the percentage of time that individuals spent building a nest, incubating, and brooding. Incubation and brooding sessions were defined as starting when a focal individual began either incubating eggs or brooding nestlings, respectively, and ending when the individual left the nest. We documented what nest materials were brought by males and females. A mirror attached to an extendable pole was used when the number of eggs was checked in two nests (Nests B and C). All statistical procedures were conducted using StatView J-4.5 (Abacus Concepts 1995). Mean values $\pm S D$ are reported in the text below.

\section{Results}

\section{Nest and home range distribution}

Five pairs (Pairs A-E) were confirmed inhabitants of the study area (Fig. 2). The home ranges of paired male and female overlapped with each other. Each polygon in Fig. 2 , therefore, shows the home range of each pair. We heard the song, but did not see the pair at southwestern part of the study area where none of Pairs A-E were observed. It was apart from the home range of Pairs A-E, therefore, we regarded it as one other pair (Pair F). Although we had too few points of encounter for Pairs $A$ and $D$ to draw a convex polygon as an estimate of home range (Fig. 2), the home range size of Pairs B, C, and E was $7.1,5.1$, and $8.8 \mathrm{ha}$, respectively. These home ranges were non-overlapping and about $100 \mathrm{~m}$ apart (Fig. 2), so it is not surprising that we observed no interaction among pairs. Three nests (A, B, and C) were found in the study area (Fig. 2), located approximately $14.5 \mathrm{~m}, 11.0 \mathrm{~m}$, and $6.5 \mathrm{~m}$ above ground, respectively. Each nest was bowl-shaped, and built in the fork of a tree. Nesting-tree DBHs were $23 \mathrm{~cm}, 22 \mathrm{~cm}$, and $21 \mathrm{~cm}$ for Nests A, $\mathrm{B}$, and $\mathrm{C}$, respectively. 

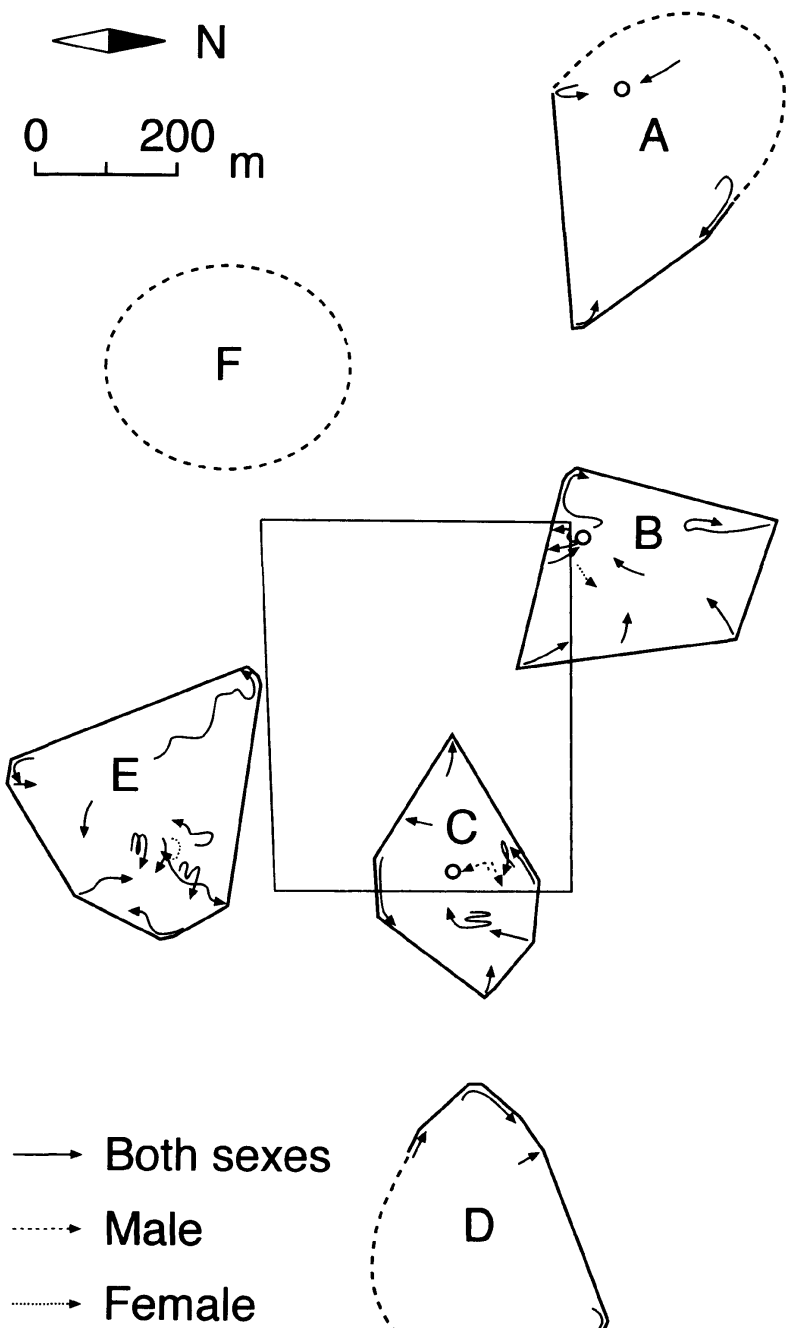

Fig. 2. Home range distribution of six pairs of Van Dam's Vanga. Nest sites are represented by small circles. Arrows are the trajectories of each pair or individual (solid lines=both sexes; broken lines $=$ males; dotted lines $=$ females). The home range polygons of Pairs $\mathbf{A}$ and $\mathbf{D}$ were not drawn because of too few points of encounter. Pair $F$ was heard singing, but not seen. The central square indicates the Jardin Botanique A research quadrat $(450 \times 550 \mathrm{~m})$.

\section{Nest-building}

Nesting material was gathered by both sexes a total of 29 times (Nest B) in 4-h observation or 10 times (Nest C) in 1-h observation. The nests consisted of plant fibers, barks, and spider threads. Both parents brought material to Nest $B$, and the male sometimes delivered material to another fork, $30 \mathrm{~cm}$ above. The male brought nesting material 12 times (41.4\% of the total frequency) including 4 times to the fork above, the 
female 17 times $(58.6 \%)$. We tested a hypothesis that males and females spent equal number of attendance at the nest for nest-building; there was no significant difference between the sexes at Nest B $(G=0.43, P=0.51)$. However, the mean duration for staying of the female in the nest was significantly longer than that of the male (mean duration for staying of the female: $70.1 \pm 56.4 \mathrm{sec}$., mean duration for staying of the male: $27.5 \pm 32.4$ sec., Mann-Whitney $U$-test, $U=40.00, P<0.01$ ). At Nest $\mathrm{C}$, the female delivered nest material 9 times, the male once. The female gathered materials more frequently than the male, and this was significantly biased from the assumption of equal provisioning by male and female $(G=4.07, P<0.05)$. The male associated closely with the female when she left the nest on 4 occasions.

\section{Clutch size and egg colour}

At Nest $\mathrm{C}$, the first egg was confirmed on 30 October, and incubation began immediately after. On 1 November, there were three eggs in the nest, indicating that one egg was laid each day. However, we failed to confirm the full clutch size at Nest C, because all of the eggs disappeared from the nest on 3 November. At Nest B, the first incubation episode (sitting on the nest) was observed on 31 October, and by 4 November, the nest held four eggs, indicating that a full clutch of this nest contains at least four eggs. We did not determine the clutch size of Nest A because the nest was too high to reach with our equipment. The eggs in Nests B and $\mathrm{C}$ were white with reddish-brown spots on the bottom.

\section{Incubation}

In all three nests combined, parents incubated eggs for a total of $97.4 \pm 2.9 \%$ of their time in the nest during a total of $30-\mathrm{h}$ observation over 9 days. Both sexes contributed to

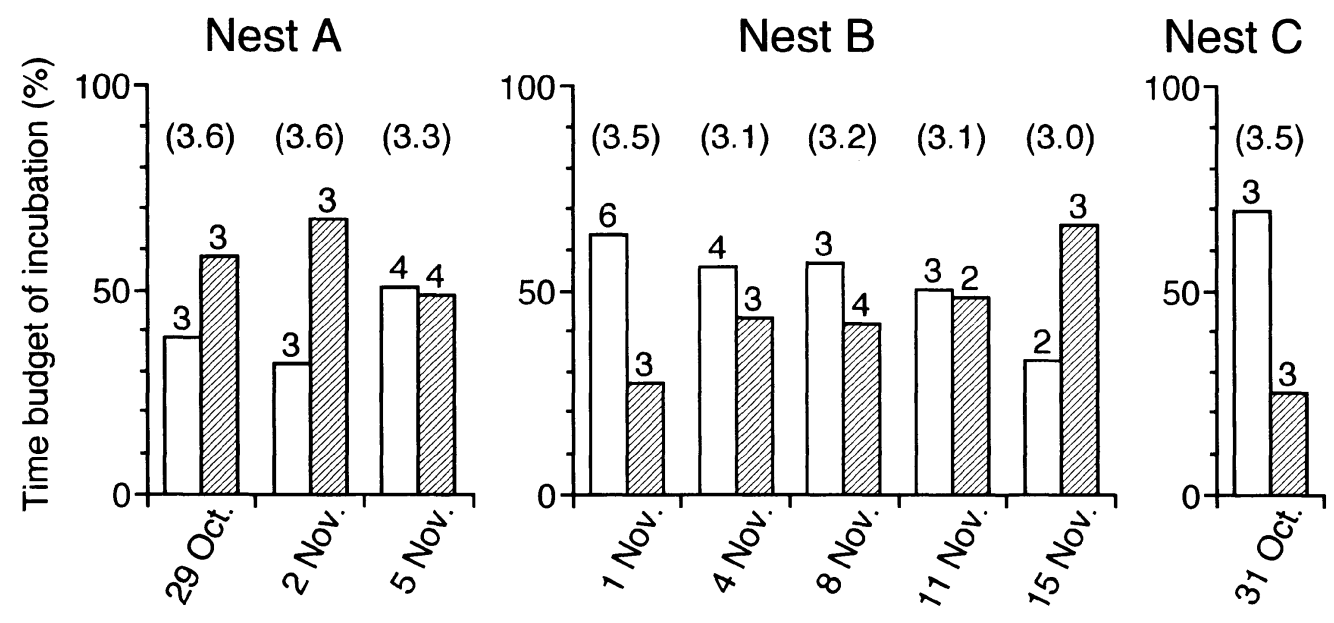

Fig. 3. Incubation time budgets of male and female Van Dam's Vanga at three nests. Open bars= males; hatched bars $=$ females. Number of incubation sessions is given above each bar. Observation time (hour) is given in parentheses. 
incubation tasks (Fig. 3). At Nest A, female incubated eggs longer than the male on 29 October and 2 November, although the number of incubation sessions was the same for each sex (Fig. 3). At Nest B, the male incubated longer than the female on 1, 4, 8 and 11 November. The male also engaged in more incubation sessions than the female on 1, 4 and 11 November, but the female initiated more on 8 November (Fig. 3). On 15 November, the female incubated longer than the male, and the female engaged in more incubation sessions than the male (Fig. 3). At Nest C, the male incubated longer than the female, although the number of incubation sessions was the same for each sex (Fig. 3). The mean duration of an incubation session was not significantly different between the sexes at Nest B (Fig. 4). However, the mean duration of incubation by the female was significantly longer than that by the male at Nest $A$ on 2 November $(49.0 \pm 16.6$ min. vs $23.1 \pm 3.1$ min.; Mann-Whitney $U$-test, $U=0.0, P<0.05$; Fig. 4). At Nest C, the male held significantly longer incubation sessions than the female $(49.0 \pm 4.7 \mathrm{~min}$. vs $17.5 \pm 18.2$ min.; Mann-Whitney $U$-test, $U=0.0, P<0.05$; Fig. 4).

No vocalizations were heard when the parents swapped incubation responsibility. The individual incubator in the nest seemed to leave the nest when they saw their mate approaching the nest, and then the mate would take over the incubation.

At Nest B, the first incubation episode was observed on 31 October. Hatching of at least one egg was confirmed on 18 November, because the first feeding events by parents were observed on the day. Therefore, the incubation stage lasted at least 18 days at this nest. We were unable to estimate the duration of the incubation stage at Nests A or C, because the eggs in these nests disappeared before the hatching.

\section{Brooding and feeding the nestlings}

In the early nestling stage, Nest B was observed for three hours on 18 and 20
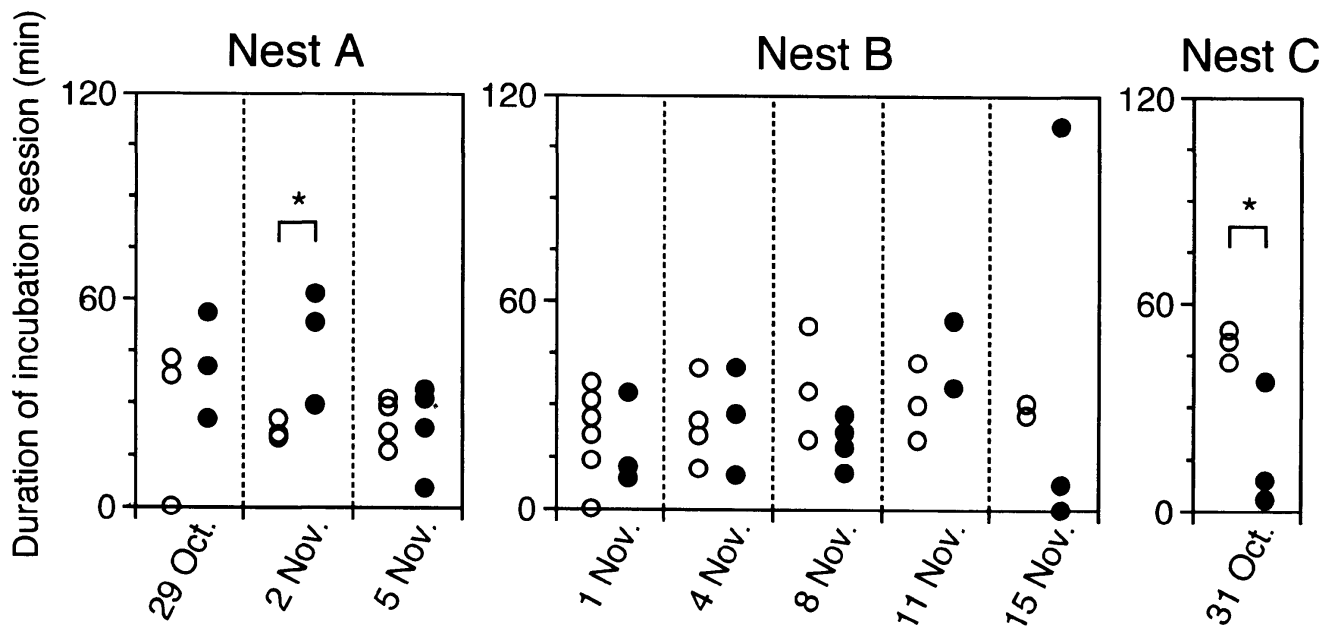

Fig. 4. Duration of each incubation session of male (open circle) and female (closed circle) Van Dam's Vanga at three nests. Observation times denoted as in Fig. 3. ${ }^{\star}$ Mann-Whitney $U$-test, $P<$ 0.05 . 

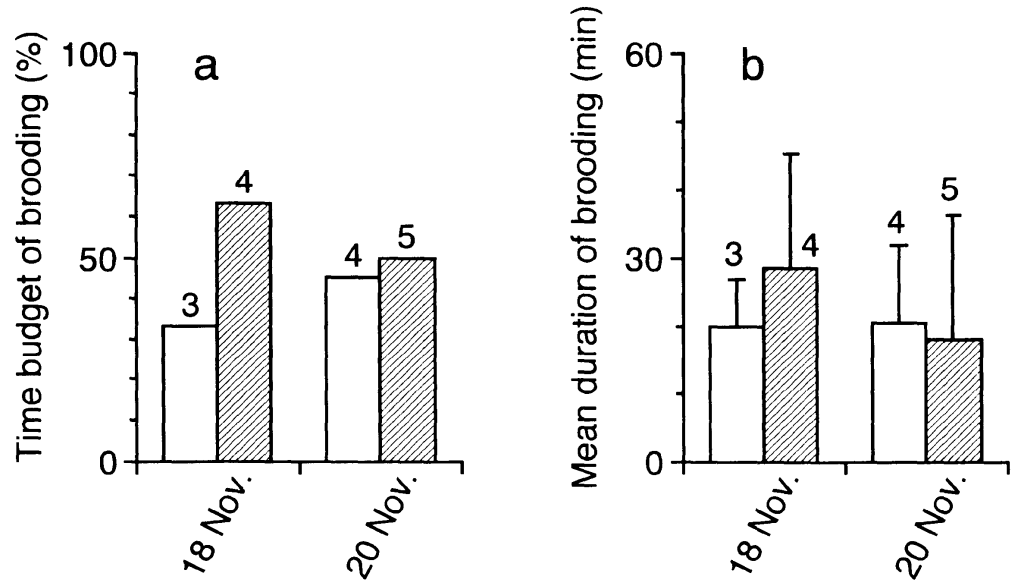

Fig. 5. Time budgets (a) and mean duration (b) of brooding by male and female Van Dam's Vanga during 3-h observations in the early nestling stage at Nest B. Open bars=males; hatched bars $=$ females. Error bars represent SD. Date of hatching was 18 November. Number of brooding sessions is given above each bar.
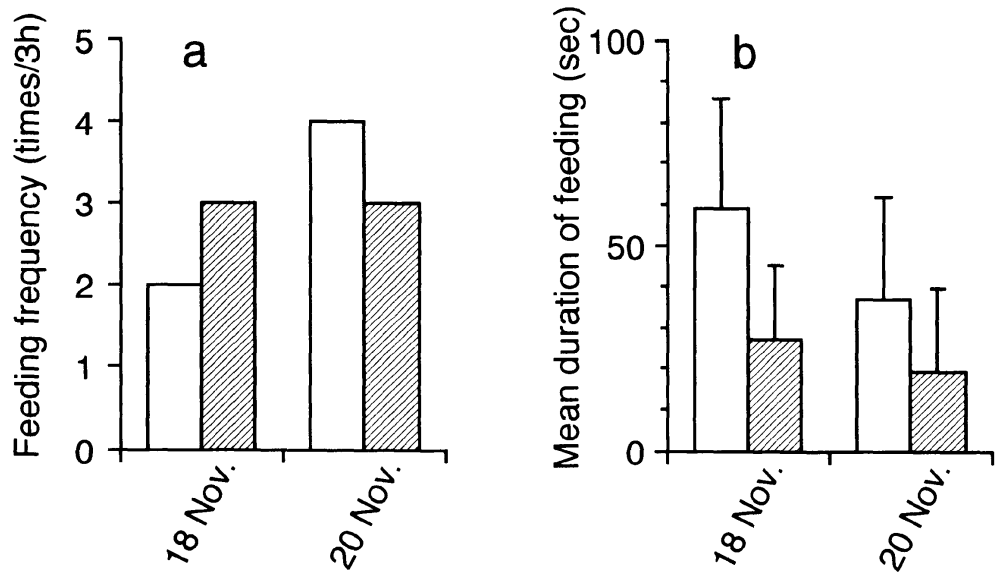

Fig. 6. Frequency (a) and mean duration (b) of feeding of male and female Van Dam's Vanga during 3-h observations in the early nestling stage at Nest B. Open bars=males; hatched bars= females. Error bars represent SD. Date of hatching was 18 November.

November. When the parents came to the nest, they fed the nestlings and sat on them to brood. During the observations of each day, the parents brooded nestlings for $98.7 \%$ and $96.7 \%$ of their total time in the nest, respectively (Fig. 5a). Mean durations of the brooding sessions were not different significantly between the male and female: $20.0 \pm 7.0$ $\min$. and $28.5 \pm 16.8 \mathrm{~min}$. on 18 November (Mann-Whitney $U$-test, $U=4.0, P=0.48$ ), and $20.5 \pm 11.3$ and $18.0 \pm 18.2 \mathrm{~min}$. $(U=8.0, P=0.62)$ on 20 November, respectively (Fig. 5 b).

On 18 November, the male came to the nest three times, and fed the nestlings twice. The female came to the nest four times, and fed the nestlings three times (Fig. 6a). On 
20 November, the male came to the nest and fed the nestlings four times; the female came four times and fed them three times (Fig. 6a). Average feeding duration did not differ significantly between the male and the female on 18 November $(59.0 \pm 26.9 \mathrm{sec}$. vs $27.0 \pm$ 18.2 sec., respectively; Mann-Whitney $U$-test, $U=1.0, P=0.25$ ) and on 20 November (36.8 \pm 25.1 sec. vs $19.3 \pm 20.5$ sec., respectively; $U=2.5, P=0.21$ ) (Fig. $6 b$ ).

When Nest B was observed on 24 November, the male came to the nest once but ate the food himself rather than feeding the nestlings. The parents did not come to the nest again. We assume that the nestlings disappeared on this day; therefore, we failed to determine the duration of the nestling period.

\section{Foraging ecology}

Although the food items given to nestlings were too small to observe using the spotting scope and video camera, we observed the foraging behaviour of this species. Individuals fed on insects extracted from dead tree trunks and branches by gleaning and probing with their large, vertically flattened bills. We observed the Pair E male capture a grasshopper, hold it down with his left leg, tear off the chitin with his bill, eat the inside, and then swallow the exoskeleton whole.

\section{Discussion}

Lack (1968) suggested that feeding habits strongly influence the evolution of solitary nesting, describing how species that feed on land animals are territorial, and feed and nest solitarily. Van Dam's Vanga feeds on insects from dead trunks and branches by gleaning and probing (Yamagishi \& Eguchi 1996, this study). The pairs of Van Dam's Vanga in this study had non-overlapping home ranges (Fig. 1), and solitary nests about $500 \mathrm{~m}$ apart. It is probable that Van Dam's Vanga is a territorial species, though territorial interaction among pairs was not observed because of their sparsely-distributed home ranges, which may be due to the small sized population (Langrand 1990). The home range of this species was rather large compared to other vangids, such as the Rufous Vanga (Schetba rufa) (Yamagishi et al. 1995) or the White-headed Vanga (Leptopterus viridis) (Nakamura et al. 2001).

Both sexes of Van Dam's Vanga participated equally in nest building, incubation, brooding and feeding of nestlings. Two individuals of the same sex did not observed to attend the nest simultaneously, and parents had the aid of no helpers for any of these nesting activities, unlike in some vangid species such as the Rufous Vanga (Yamagishi et al. 1995) and Chabert's Vanga (Leptopterus chabert) (Appert 1970). According to Ligon (1999), social monogamy is defined by an apparently exclusive association of one female and one male that are mates over some definable period of time; the relationship is often characterized by biparental care. What we know about Van Dam's Vanga appears to fit the definition, and we therefore conclude that the mating system of this species is best described as socially monogamous.

The breeding ecology of Van Dam's Vanga is very similar to that of another Xenopirostris species, Pollen's Vanga (X. polleni), reported by Putnam (1996). The clutch 
sizes of the two differ; that of Pollen's Vanga was reported to be two eggs (Langrand 1990, Safford \& Duckworth 1990, Putnam 1996), while that of Van Dam's Vanga was at least four eggs, which was first confirmed in the present study. Langrand (1990) reported that the other Xenopirostris species, Lafresnaye's Vanga ( $X$. xenopirostris) has also the clutch size of two eggs. These three Xenopirostris species are allopatrically-distributed. Van Dam's Vanga inhabits western deciduous dry forests, Pollen's Vanga inhabits eastern rain forests, and Lafresnaye's Vanga inhabits southern subarid areas (Langrand 1990). Future studies should address whether breeding ecology is related to habitat in each species, and compare the relationships among them.

\section{Acknowledgements}

We are grateful to the director, Albert Randrianjafy, and other staff of Parc Botanique et Zoologique de Tsimbazaza for their cooperation in the realization of the present project. Our hearty thanks also go to the staff of ANGAP for accommodation and facilities at Ampijoroa Forest Station. We thank Drs. M. Hasegawa, A. Mori, T. Hikida, H. Rakotomanana, Messrs. S. Asai, I. Ikeuchi, T. Okamiya, G. Razafindrakoto, and Ms. H. Rakotonindrainy for their assistance in the field. We also express our thanks to the two anonymous referees for their constructive comments and suggestions. This study was supported by a Grant under the Monbusho International Scientific Research Program (Field Research, No. 11691183).

\section{References}

Appert, O. 1970. Zur Biologie der Vangawiirger (Vangidae) Südwest-Madagaskars. Ornithol. Beob. 67: 101133.

Goodman, S. M., Hawkins, A. F. A. \& Domergue, C. A. 1997. A new species of vanga (Vangidae, Calicalicus) from southwestern Madagascar. Bulletin of the British Ornithologists' Club 117: 5-10.

Lack, D. 1968. Ecological Adaptations for Breeding in Birds. Methuen \& Co. Ltd., London. pp. 145-146.

Langrand, O. 1990. Guide to the Birds of Madagascar. Yale University Press, New Heaven and London.

Ligon, J. D. 1999. The evolution of avian breeding system. Oxford University Press, Oxford. pp. 259-286.

Morris, P. \& Hawkins, F. 1998. Birds of Madagascar. A photographic guide. Yale University Press, New Heaven and London. 248 pp.

Nakamura, M., Yamagishi, S. \& Nishiumi, I. 2001. Cooperative Breeding in the White-headed Vanga Leptopterus viridis, Which is Endemic to Madagascar. J. Yamashina Inst. Ornithol. 33: 1-14 .

Putnam, M. S. 1996. Aspects of the breeding biology of Pollen's Vanga (Xenopirostris polleni) in southeastern Madagascar. Auk 113: 233-236.

Rakotomanana, H., Nakamura, M., Yamagishi, S. \& Chiba, A. 2000. Incubation Ecology of Helmet Vangas Euryceros prevostii, Which Are Endemic to Madagascar. J. Yamashina Inst. Ornithol. 32: 68-72.

Safford, R. \& Duckworth, W. (Eds.) 1990. A wildlife survey of Marojejy Nature Reserve, Madagascar. Int. Counc. Bird Preserv. Study Rep. 40: 1-172.

Yamagishi, S. \& Eguchi, K. 1996. Comparative foraging ecology of Madagascar vangids (Vangidae). Ibis 138: 283-290.

Yamagishi, S., Urano, E. \& Eguchi, K. 1995. Group composition and contributions to breeding by Rufous Vangas Schetba rufa in Madagascar. Ibis 137: 157-161.

Yamagishi, S., Honda, M., Eguchi, K. \& Thorstrom, R. 2001. Extreme endemic radiation of the Malagasy 
Vangas (Aves: Passeriformes). J. Mol. Evol. 53: 39-46.

マダガスカル特産種シロノドオオハシモズ Xenopirostris damii の繁殖生態

オオ八シモズ科鳥類は，マダガスカル島内で著しく適応放散した単系統種群である。これま でオオハシモズ科鳥類の採食生態や系統関係については研究が行われているが，各種の基本的 な繁殖生態についてはほとんどわかっていない。本論文ではオオ八シモズ科鳥類の一種シロ) ドオオ八シモズの繁殖生態を記載し，その配偶様式を考察した。調査は 2000 年の 10 月から 11 月にかけて, マダガスカル北西部の落葉乾燥林アンカラファンチカ厳正保護区内アンピジュル ア研究林において行った。調査地では声のみが聞かれた 1 番いを含む 6 番いのシロノドオオ八 シモズが確認された。各番いは分散した行動圏を所有しており，各行動圏は互いに接しておら ず，番い間の干渉は観察されなかった。巣が発見された 3 番いについて，造巣，抱卵，育雊行 動を観察したが，いずれの行動も雌雄が分担して行っていた。繁殖活動を手伝うへルパー個体 は観察されなかった。これら分散した行動圏を持つことと雌雄 2 個体が卵および雛の世話を行 うことから，シロノドオオ八シモズの配偶様式は一夫一妻であると考えられた。

水田 拓： 京都大学大学院理学研究科動物行動学研究室. 干606-8502 京都市左京区北白川 追分町. E-mail: mizutaku@ci.zool.kyoto-u.ac.jp

中村雅彦：上越教育大学生物学教室動物生態学研究室. $=943-8512$ 新潟県上越市山屋敷町 1 番地. E-mail: masahiko@juen.ac.jp

山岸 哲：京都大学大学院理学研究科動物行動学研究室. 干606-8502 京都市左京区北白川 追分町. E-mail: yama@ci.zool.kyoto-u.ac.jp 